\title{
Learn the operating system material and understand deepening of existing material
}

\section{ILHAM FITRA PRATAMA}

195120007

Fakultas Komputer

ilhaamfitrapratama@umitra.ac.id

\begin{abstract}
Abstrack :
Suatu sistem operasi modern merupakan suatu sistem yang besar dan kompleks sehingga strukturnya harus dirancang dengan hati-hati dan saksama supaya dapat berfungsi seperti yang diinginkan serta dapat dimodifikasi dengan mudah.
\end{abstract}

Struktur sistem operasi merupakan komponen-komponen sistem operasi yang dihubungkan dan dibentuk di dalam kernel.

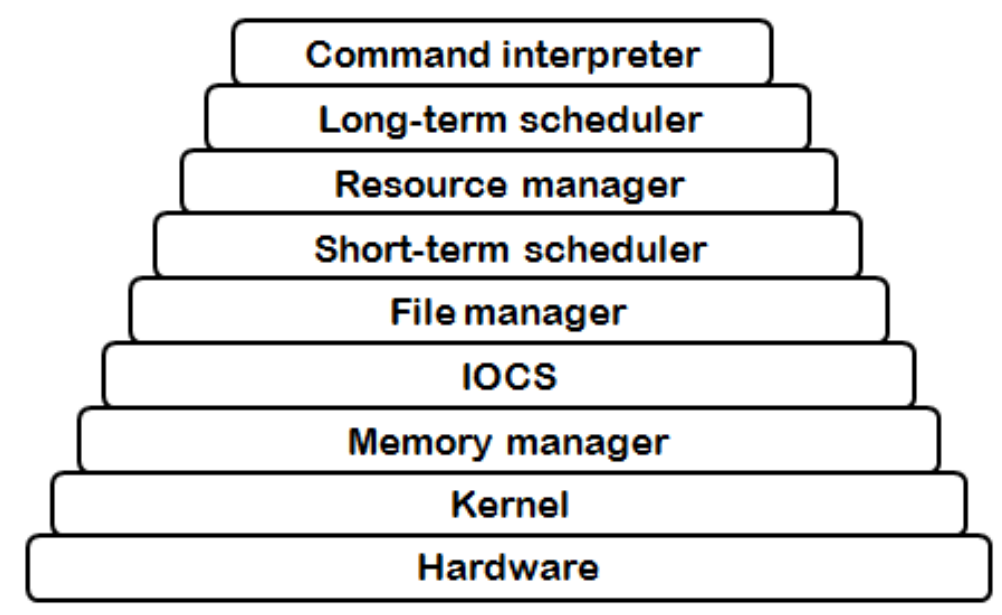

Ada beberapa struktur sistem operasi dan pernah dicoba, diantaranya sebagai berikut. 


\section{STRUKTUR MONOLITHIC}

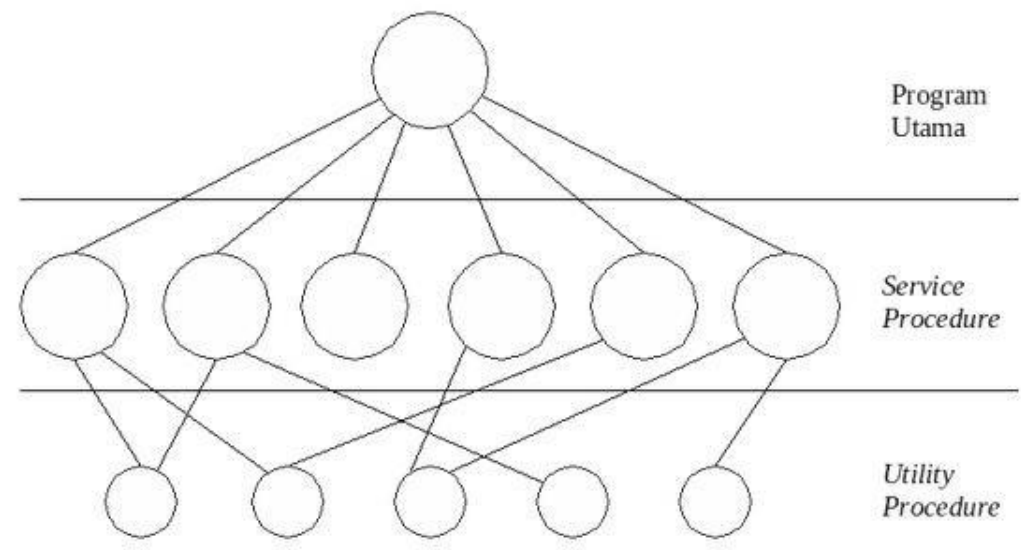

Struktur sistem operasi di sistem ini tidak terstruktur. Sistem operasi sebagai kumpulan prosedur yang masing-masing dapat saling dipanggil jika dibutuhkan. Setiap prosedur yang ada di dalam sistem ini mempunyai interface yang sudah didefinisikan dengan baik. Dalam hal ini berupa parameter dan hasilnya, serta masing-masing prosedur bebas untuk saling memanggil jika dibutuhkan. Walaupun disebut tidak berstruktur, sebenarnya sistem monilisthic tetap mempunyai struktur walaupun kecil dan mendasar. Struktur tersebut adalah:

$>$-Program utama yang meminta layanan prosedur.

$>$-Kumpulan layanan prosedur yang membawa sistem call .

$>$-Kumpulan utilitas prosedur yang membantu layanan prosedur.

Dalam model ini setiap sistem call mempunyai suatu prosedur yang akan mengelolanya. Utilitas prosedur mengerjakan suatu hal yang diinginkan oleh beberapa layanan prosedur. 


\section{STRUKTUR LAPISAN ( THE )}

Sistem pertama yang dibangun dengan sistem lapisan adalah THE yang dibuat di Technische Hogeschool Eindhoven, Belanda pada tahun 1968 oleh E.W. Dijkstra dan para mahasiswanya.Sistem ini mempunyai enam lapis.

\begin{tabular}{|l|l|l|}
\hline \multicolumn{1}{|c|}{ Lapisan } & \multicolumn{1}{|c|}{ Nama } & \multicolumn{1}{c|}{ Fungsi } \\
\hline Lapisan - 5 & Uscr Program & Untuk program Pemakai \\
\hline Lapisan - 4 & Buffering untuk I/O device & Penyederhana akses I/O pada level atas \\
\hline Lapisan - 3 & Operator-console device driver & Mengantur komunikasi antar proses \\
\hline Lapisan - 2 & Manajemen memori & Pengalokasian ruang memori \\
\hline Lapisan - 1 & Penjadwalan CPU & $\begin{array}{l}\text { Mengatur alokasi CPU dan switching } \\
\text { pengaturan prosessor }\end{array}$ \\
\hline Lapisan - 0 & Hardware & $\begin{array}{l}\text { Untuk operator dan menjalan } \\
\text { keseluruhan sistem }\end{array}$ \\
\hline
\end{tabular}

Contoh sistem operasi yang menggunakan sistem ini adalah: UNIX termodifikasi, THE, Venus dan OS/2

Teknik pendekatan terlapis pada dasarnya dibuat dengan menggunakan pendekatan top-down, semua fungsi ditentukan dan dibagi menjadi komponen komponen. Modularisasi sistem dilakukan dengan cara memecah sistem operasi menajdi beberapa lapis (tingkat). Lapisan terendah (layer 0) adalah perangkat keras dan lapisan teratas (layer N) adalah user interface. Dengan system modularisasi, setiap lapisan mempunyai fungsi (operasi) tertentu dan melayani lapisan yang lebih rendah.

\section{STRUKTUR LAPISAN ( VENUS )}

Sistem Venus yang mempunyai tujuh lapisan. Lapisan bawah (0 sampai 4) digunakan oleh penjadwalan CPU dan manajemen memori yang kemudian diletakkan dalam suatu microcode. Pengaturan ini memberikan keuntungan, seperti eksekusi yang lebih cepat dan interface yang didefinisikan menjadi lebih jelas antara lapisan microcode dengan lapisan yang lebih tinggi.

\begin{tabular}{lll} 
Lapis-6 & $:$ & user program \\
Lapis-5 & $:$ & device driver dan sceduler \\
\hline Lapis-4 & $:$ & virtual memory \\
Lapis-3 & $:$ & I/O channel \\
\hline Lapis-2 & $:$ & penjadwalan CPU \\
\hline Lapis-1 & $:$ & instruksi interpreter \\
\hline Lapis-0 & $:$ & hardware
\end{tabular}




\section{MESIN VIRTUAL}

Konsep dasar dari mesin virtual ini tidak jauh berbeda dengan pendekatan terlapis, hanya saja konsep ini memberikan sedikit tambahan berupa antarmuka yang menghubungkan perangkat keras dengan kernel untuk tiap-tiap proses, Gambar 2-9 menunjukkan konsep tersebut. Mesin virtual menyediakan antar muka yang identik untuk perangkat keras yang ada. Sistem operasi membuat ilusi untuk beberapa proses, masing-masing mengeksekusi prosessor masing-masing untuk memori (virtual) masing-masing.

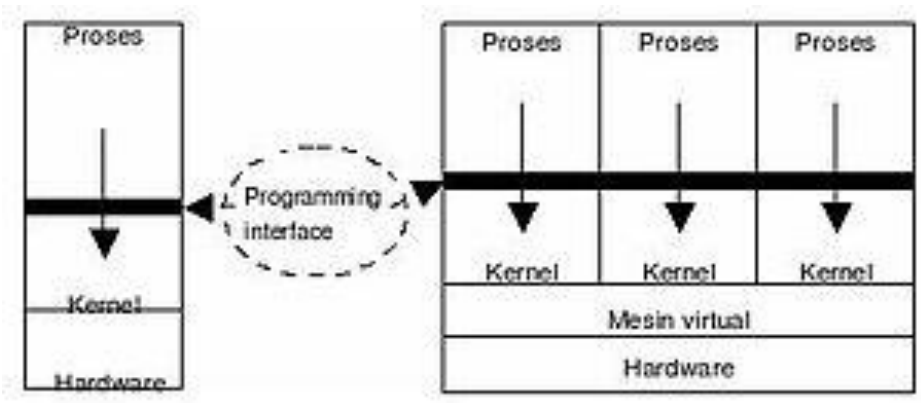

/Contoh sistem operasi yang memakai mesin virtual adalah IBM VM system.

Keuntungan dan kerugian konsep mesin virtual adalah sebagai berikut :

- Konsep mesin virtual menyediakan proteksi yang lengkap untuk sumber daya system sehingga masing-masing mesin virtual dipisahkan mesin virtual yang lain. Isolasi ini tidak memperbolehkan pembagian sumber daya secara langsung

- Sistem mesin virtual adalah mesin yang sempurna untuk riset dan pengembangan system operasi. Pengembangan system dikerjakan pada mesin virtual, termasuk di dalamnya mesin fisik dan tidak mengganggu operasi system yang normal.

- Konsep mesin virtual sangat sulit untuk mengimplementasikan kebutuhan dan duplikasi yang tepat pada mesin yang sebenarnya. 


\section{MODEL CLIENT SERVER}

Dalam model ini, semua kernel bekerja menangani komunikasi antara server dan client. Dengan membagi sistem operasi menjadi banyak bagian yang masing-masing hanya menangani bagian tertentu dari sistem. Seperti layanan file, layanan proses, layanan terminal atau layanan memori, maka setiap bagian menjadi lebih kecil dan lebih mudah diatur. Kemudian semua server berjalan daam proses user mode dan tidak dalam kernel mode, maka bagian-bagian tidak mempunyai akses langsung ke perangkat keras.

Keuntungannya, bila ada kesalahan di file server, maka layanan file mungkin akan crash, tetapi tidak akan mempengaruhi keseluruhan sistem, yang akhirnya dapat mengakibatkan keseluruhan sistem tidak berfungsi.

Keuntungan lain dari sebuah model client-server adalah dapat diadaptasi untuk digunakan dalam sistem terdistribusi Jika client berkomunikasi dengan server dengan mengirimkan pesan, klien tidak perlu tahu pesan tersebut ditangani secara local daam mesinnya sendiri atau pesan tersebut dikirimkan malalui jaringan ke servel di mesin yang lain.

Contoh Sistem operasi yang menggunakan struktur ini adalah : Windows Server, Linux

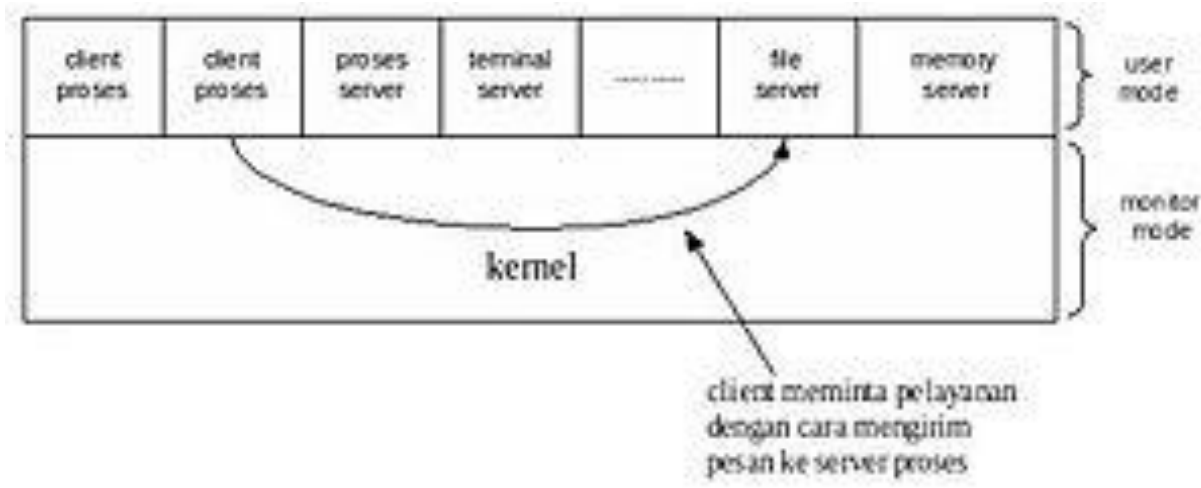


Keywords : Struktur Sistem Operasi.

A. ID SECURITY

QWTD44112377-ASP-524414475

\section{B. REFERENCE}

[1] O. M. Febriani and A. S. Putra, "Sistem Informasi Monitoring Inventori Barang Pada Balai Riset Standardisasi Industri Bandar Lampung," J. Inform., vol. 13, no. 1, pp. 90-98, 2014.

[2] A. S. Putra, "Paperplain: Execution Fundamental Create Application With Borland Delphi 7.0 University Of Mitra Indonesia," 2018.

[3] A. S. Putra, "2018 Artikel Struktur Data, Audit Dan Jaringan Komputer," 2018.

[4] A. S. Putra, "ALIAS MANAGER USED IN DATABASE DESKTOP STUDI CASE DB DEMOS."

[5] A. S. Putra, "COMPREHENSIVE SET OF PROFESSIONAL FOR DISTRIBUTE COMPUTING."

[6] A. S. Putra, "DATA ORIENTED RECOGNITION IN BORLAND DELPHI 7.0."

[7] A. S. Putra, "EMBARCADERO DELPHI XE 2 IN GPUPOWERED FIREMONKEY APPLICATION."

[8] A. S. Putra, "HAK ATAS KEKAYAAN INTELEKTUAL DALAM DUNIA TEKNOLOGY BERBASIS REVOLUSI INDUSTRI 4.0."

[9] A. S. Putra, "IMPLEMENTASI PERATURAN PERUNDANGAN UU. NO 31

$\begin{array}{lr}\text { TAHUN } 2000 & \text { TENTANG } \\ \text { DESAIN } & \text { INDUSTRI } \\ \text { BERBASIS INFORMATION } \\ \text { TECHNOLOGY." }\end{array}$

$\begin{array}{lr}\text { A. S. } & \text { Putra, } \\ \text { "IMPLEMENTATION } & \text { OF }\end{array}$

A. S. Putra, "IMPLEMENTATION OF TRADE SECRET CASE STUDY SAMSUNG MOBILE PHONE."

[12] A. S. Putra, "IMPLEMENTATION PATENT FOR APPLICATION WEB BASED CASE STUDI WWW. PUBLIKLAMPUNG. COM."

A. S. Putra, "IMPLEMENTATION SYSTEM FIRST TO INVENT IN DIGITALLY INDUSTRY."

[14] A. S. Putra, "MANUAL REPORT \& INTEGRATED DEVELOPMENT

ENVIRONMENT BORLAND DELPHI 7.0."

[15] A. S. Putra, "PATENT AS RELEVAN SUPPORT RESEARCH."

[16] A. S. Putra, "PATENT FOR RESEARCH STUDY CASE OF APPLE. Inc."

[17] A. S. Putra, "PATENT PROTECTION FOR APPLICATION INVENT."

[18] A. S. Putra, "QUICK REPORT IN

PROPERTY 
PROGRAMMING."

A. S. Putra, "REVIEW
CIRCUIT
LAYOUT
REQUIREMENT ON ASUNENT
NOTEBOOK."

[20] A. S. Putra, "REVIEW TRADEMARK PATENT FOR INDUSTRIAL TECHNOLOGY BASED 4.0."

[21] A. S. Putra, "TOOLBAR COMPONENT PALLETTE IN OBJECT ORIENTED PROGRAMMING."

[22] A. S. Putra, "WORKING DIRECTORY SET FOR PARADOX 7."

[23] A. S. Putra, "ZQUERY CONNECTION IMPLEMENTED PROGRAMMING STUDI CASE PT. BANK BCA Tbk."

[24] A. S. Putra, D. R. Aryanti, and I. Hartati, "Metode SAW (Simple Additive Weighting) sebagai Sistem Pendukung Keputusan Guru Berprestasi (Studi Kasus: SMK Global Surya)," in Prosiding Seminar Nasional Darmajaya, 2018, vol. 1, no. 1, pp. 85-97.

[25] A. S. Putra and O. M. Febriani,
"Knowledge Management Online Application in PDAM Lampung Province," in Prosiding International conference on Information Technology and Business (ICITB), 2018, pp. 181-187.

[26] A. S. Putra, O. M. Febriani, and B. Bachry, "Implementasi Genetic Fuzzy System Untuk Mengidentifikasi Hasil Curian Kendaraan Bermotor Di Polda Lampung," SIMADA (Jurnal Sist. Inf. dan Manaj. Basis Data), vol. 1, no. 1, pp. 21-30, 2018.

[27] A. S. Putra, H. Sukri, and K. Zuhri, "Sistem Monitoring Realtime Jaringan Irigasi Desa (JIDES) Dengan Konsep Jaringan Sensor Nirkabel," IJEIS (Indonesian J. Electron. Instrum. Syst., vol. 8, no. 2, pp. 221-232.

[28] D. P. Sari, O. M. Febriani, and A. S. Putra, "Perancangan Sistem Informasi SDM Berprestasi pada SD Global Surya," in Prosiding Seminar Nasional Darmajaya, 2018, vol. 1, no. 1, pp. 289-294. 